\title{
Financing Sustainable Development: Country Undertakings and Rights for Environmental Sustainability (CURES)
}

\author{
By \\ R. Quentin Grafton ${ }^{\mathrm{a}, *}$, \\ Centre for Resource and Environmental Studies \\ The Australian National University \\ Frank Jotzo ${ }^{\mathrm{a}}$, \\ Centre for Resource and Environmental Studies \\ The Australian National University \\ and
}

Cooperative Research Centre for Greenhouse Accounting, Canberra

Merrilyn Wasson ${ }^{b}$

Research School for Pacific and Asian Studies

The Australian National University

\footnotetext{
${ }^{a}$ Center for Resource and Environmental Studies

Hancock Building (Bldg. 43)

The Australian National University

Canberra, ACT 0200

Australia

${ }^{\mathrm{b}} R M A P$

Research School of Pacific and Asian Studies

Coombs Building

The Australian National University

Canberra, ACT 0200

Australia
}

*Corresponding author. e-mail: qgrafton@cres.anu.edu.au, tel +61-2-6125-0663, fax:

$+61-2-6125-0757$

E-mail addresses: jotzo@cres.anu.edu.au \& merrilyn@,coombs.anu.edu.au

\section{Revised Manuscript \\ April 2004}




\begin{abstract}
We propose a global mechanism to finance sustainable development (SD) that offers a number of advantages over the current Global Environmental Facility (GEF). The mechanism would be multinational, provide incentives for rich and poor countries to promote $\mathrm{SD}$, incorporate the principle of common, but differentiated, responsibilities and link incentives and funding for SD to structural benchmarks and performance targets. It would operate as a large fund into which rich countries would pay based on their level of population, per capita income and change in a measure of environmental sustainability. Receipts from the funds, called Country Undertakings and Rights for Environmental Sustainability (CURES), would be made to poor countries based on their population, per capita income and absolute level of environmental sustainability. This approach differentiates payments and receipts on the basis of income, while rewarding improvements in environmental performance in rich countries, and making greater payments to countries with greater environmental problems. To promote flexibility, recipient countries would be able to trade, bank or borrow their assigned CURES, provided that the trade resulted in a verifiable improvement in environmental sustainability in the purchasing country. A reformed GEF that adopted the desirable features of CURES, if widely adopted and funded at a sufficiently high level, would offer a significant boost to global SD and would greatly assist poor countries to address the twin challenges of poverty and environmental degradation.
\end{abstract}

Keywords: sustainable development, intergovernmental financial transfers, adjusted net savings, GEF 
The special situation and needs of developing countries, particularly the least developed and those most environmentally vulnerable, shall be given special priority. International actions in the field of environment and development should also address the interests and needs of all countries.

Principle 6, Rio Declaration on Environment and Development at The United Nations Conference on Environment and Development (12 August 1992).

\section{Introduction}

Sustainable development (SD) became a widely accepted policy objective following the release of the report of the World Commission on Environment and Development (WCED) in 1987. Its focus on the need for a collective resolution of global environmental problems led to the 1992 United Nations Conference on Environment and Development (UNCED). Three important developments that came from UNCED include The United Nations Convention to Combat Desertification (UNCD), The United Nations Convention on Biological Diversity (UNCBD) and The United Nations Framework Convention on Climate Change (UNFCCC). Under all three agreements is the notion of 'common but differentiated responsibilities', that all countries bear a responsibility to address environmental challenges, but rich countries acknowledge a special responsibility in terms of supplying technologies and financial resources in the pursuit of SD. This principle was reaffirmed at the World Summit on Sustainable Development (WSSD) held in 2002, which also called for common efforts to be made to promote the integration of economic development, social development and environmental protection as mutually reinforcing components of sustainable development (United Nations 2002).

One of the mechanisms for achieving common, but differentiated, responsibilities is the Global Environmental Facility (GEF). The GEF is funded by rich nations and makes 
transfers to poor countries to achieve specific environmental outcomes. As of February 2002 , the GEF had authorized payments to poor countries totaling over US\$2 billion (World Bank 2002a) to cover the incremental costs associated with combating climate change, loss of biodiversity, degradation of international waters, stratospheric ozone depletion and persistent organic pollutants (World Bank 2002b). Despite these payments and the existence of United Nations conventions on the global environment, fully integrated and effective global policies to improve overall environmental quality, especially in poor countries, have yet to fully materialize.

The principal difficulties in improving environmental quality include the linking of the different causes and solutions to environmental degradation and the financing of projects that promote SD and capacity development, especially in poor countries. To help overcome these challenges, we propose an innovative global mechanism called Country Undertakings and Rights for Environmental Sustainability (CURES) to promote SD in both rich and poor countries, while recognizing common, but differentiated, responsibilities. In section 2 we present criteria that any global mechanism should fulfill to achieve the stated objectives of the UNCED and the WSSD. In section 3 we illustrate how CURES could be implemented with a numerical example. To show how the funds transferred under CURES might be utilized, we describe a potential application in Indonesia in section 4. Section 5 lists the advantages of CURES relative to the GEF, and argues that the GEF should be reformed to incorporate the desirable features of CURES. Concluding remarks are offered in section 6 . 


\section{Global Mechanisms for Sustainable Development}

Attempts have been made to address global environmental problems multilaterally through a variety of international conventions. A difficulty with such an approach is that it may be possible for a country to meet its international treaty obligations in terms of biodiversity, desertification, climate change and trans-boundary pollution, but for its environmental quality to decline. This may arise because of negative spillovers from other countries, or because of other causes of environmental degradation not specified under existing conventions.

The issue is not that multilateral conventions are inappropriate, but that they are insufficient. In particular, there is insufficient funding under existing conventions and inadequate incentives for both donor and recipient countries to effectively address national, regional and global environmental problems. If the plan of action of the WSSD is to be realized new mechanisms that complement existing conventions are required. Some of these mechanisms are currently being developed such as "partnerships for sustainable development' and some are partially in place, such as the GEF. Further developments in both funding and incentive mechanisms to promote global sustainable development are almost certainly required if the ambitious goals of the WSSD are to be realized. The minimum conditions required of global mechanisms that promote SD are that they involve as many countries as possible, provide financial incentives for both rich and poor countries to promote $\mathrm{SD}$, incorporate the principle of common, but differentiated, responsibilities and link incentives, finance and resources for SD to 
measurable and accepted performance targets. Using these four principles, we present an innovative funding and incentive mechanism for global SD — Country Undertakings and Rights for Environmental Sustainability.

\section{Country Undertakings and Rights for Environmental Sustainability (CURES)}

CURES would operate as a large fund into which rich countries would pay based on their level of population, a suitably defined income measure (such as GDP per capita) and the change in environmental sustainability. Contributions and receipts from the fund would be determined by a transparent funding formula that would encompass any project (small or large) provided that it promoted environmental sustainability.

CURES receipts to recipient countries would resemble various direct payment initiatives that have been proposed for specific purposes, such as to maintain biodiversity (Ferraro and Kiss 2002) and reduce deforestation (van Soest and Lensink 2000). Two unique features of CURES would be, one, receipts could be spent on any project that contributes to environmental sustainability and two, could be traded across countries and over time. Transfers from the fund would be made to poor countries, below a given income threshold, based on their level of population, a suitable per capita income measure and an absolute level of environmental sustainability. This funding formula would allow for a smooth transition from recipient to donor countries. For instance, a recipient country very close to the income threshold would receive very little in CURES funding, while a donor country just above the per capita income threshold would pay only a small contribution. 
In keeping with United Nations international conventions, the mechanism for promoting SD would be determined on a national basis. However, the implementation of projects and undertakings to promote environmental sustainability would almost certainly involve partnerships between communities, different levels of government, nongovernmental organizations and private enterprises. Actual receipts, rather than the right to receive receipts from the fund, would be conditional on ensuring that any transfers to a country were spent on projects that promote environmental sustainability with verifiable performance criteria.

Recipient countries would be assigned rights (called CURES) to receive payments from the fund, contingent on meeting the fund's criteria for its expenditure. Countries that get assigned CURES would be able to sell them to other recipient countries. The trade would be permitted by the fund provided that it resulted in a verifiable improvement in environmental sustainability in the purchasing country. This would allow for maximum flexibility and would help direct funds to where they have the highest perceived returns. Countries could also bank or borrow CURES directly with the fund or through inter-temporal trades with other recipient countries. Thus a country could arrange to 'borrow' a CURES receipt from another recipient country provided that it returned an agreed to CURES receipt at an agreed date. This would allow a country to borrow additional funds for up-front investment in particular programs, or bank CURES if its absorption capacity had not caught up with its allocation.

\subsection{Calculating CURES}


Each country's contributions to, or receipts from the CURES fund, would be calculated using appropriately defined measures of population size, per capita income and environmental sustainability. Countries would be split into either a contributor or a recipient group based on a per capita income threshold. Rich countries would pay into the fund (a higher income implies a larger contribution) while poor nations would receive CURES receipts from it (a lower income implies a larger receipt). In addition to the per capita income threshold, the actual amount paid or received by each country would depend on its population (a larger population implies a greater contribution or a larger receipt) and level of environmental sustainability (better relative performance reduces both contributions and receipts). Different weights could also be assigned to each of three factors (population, per capita income and environmental sustainability) so as to give greater importance to any one of them. The appropriate weighting of the factors and the choice of the indicators for per capita income and environmental sustainability would be subject to international negotiations prior to the establishment of CURES.

One way to calculate contributions and receipts is to derive a country factor derived from agreed-to measures of population size, per capita income and environmental sustainability. For ease of calculation and comparability, these measures would be normalized to be between 0 and 1, where a higher score implies either a larger contribution for a rich country, or a larger CURES receipt for a poor country. A value equal to, or below, the lower boundary of one of the three measures would be assigned a zero score, while a value at or above the upper boundary would be assigned a score of unity. Multiplying the normalized population, per capita income and environmental sustainability factors gives the country factor. For the two groups of countries, donors 
and recipients, the country factors by donors would be used separately to determine relative contributions for donors, and the country factors for recipient countries to determine the proportional allocation of receipts to recipients.

To calculate the dollar contribution or receipt for each country, each CURES country factor would be multiplied by a uniform adjustment factor that would ensure the total contribution and receipts equal the desired total size of the fund, less administrative costs. Thus a donor nation with a country factor twice that of another donor would contribute twice as much into the fund, but the actual contributions in dollar terms would depend on the size of the fund. Contributions to CURES, however, would not preclude rich countries from providing additional overseas development assistance (ODA) to meet the aid target of 0.7 per cent of GNP that was reaffirmed by over 150 countries at the UNCED.

A feature of the CURES formula is that if any of the three determining factors were zero, the CURES country factor would also be zero such that the country would make a zero contribution (if a rich country) or becomes ineligible for a CURES receipt (if a poor country). Thus a country in the contributors group that is very close to the per capita income threshold would score an income factor close to zero and would contribute very little into the fund. Similarly, the best environmental performance would be 'rewarded' with a zero environmental factor, exempting that country from having to make contributions and thus providing an added incentive to promote environmental sustainability.

\subsection{Choice of an environmental measure}


To calculate contributions and CURES receipts, an acceptable measure of environmental sustainability is required. Given that environmental performance and sustainability cover many dimensions, a composite of different aspects of the environment and development would be best. For illustrative purposes only, and to show how CURES might be calculated, we use adjusted net savings (formerly called genuine savings) as a measure of environmental sustainability. It represents traditional net savings (gross national product less aggregate consumption less depreciation of produced capital) plus current education expenditures less the natural depletion in natural resources valued at the resource rental rate and less the net increase in stock pollutants valued at the marginal social cost of pollution (Hamilton and Clemens, 1999).

Whether adjusted net savings would be used in calculating CURES would, however, depend on the outcome of international negotiations over the appropriate indicators to use in the funding formula. Although by no means a perfect measure of environmental sustainability, adjusted net savings does have a number of advantages over alternatives as a measure of environmental sustainability. First, it can be independently calculated from the system of national accounts with an established methodology, and thus is relatively 'tamper proof', and is also available for almost every country and over several years. Second, it is a broad measure of sustainable development and includes investments in human and produced capital as contributing to sustainability. Third, it is an accepted measure of sustainability and superior to other widely used indexes (Pearce et al. 1996), such as the human development index (Neumayer 2001). Fourth, adjusted net savings is flexible and can be modified (subject to negotiation) to reflect different SD priorities. For 
instance, it could be changed to either not include investments in human capital or to enlarge the allowable deductions from natural capital in the calculation of net savings.

For donor countries, we use the change in adjusted net savings through time, rather than comparing levels of adjusted net savings across countries to determine the level of contributions. This provides an additional incentive for rich countries to improve environmental sustainability as efforts to improve this measure are much more directly rewarded than if absolute levels of adjusted net savings were used. It also overcomes the potential problem that the measure depends, in part, on structural characteristics of countries. Further, the change in adjusted net savings is not correlated with income levels. This relationship is illustrated in Figure 1 where the change is calculated based on a five-year moving average.

[Put Figure 1 here]

By contrast to donor countries, it is desirable to differentiate CURES receipts according to structural characteristics so as to direct funds to countries with the greatest need. Figure 2 shows that adjusted net savings, as a percentage of GDP, vary enormously between countries, from below minus 30 to above plus 30 per cent. Negative adjusted net savings can be interpreted as an indicator of non-sustainability as it implies that the value of depletion of natural resources and cumulative pollution exceeds the national investment in produced and human capital. Despite the high variance, there is an identifiable positive correlation between adjusted net savings and income per capita. 
[Put Figure 2 here]

\subsection{A Numerical Example}

To illustrate the relative contributions into and receipts from a CURES fund by country, we assume a CURES fund size of US\$10 billion per year. Regardless of the size of the CURES fund, the relative contributions to and receipts from the fund would be determined by the calculated country factors. Banking and borrowing in each year would be approximately balanced. The choice of the actual fund size would depend on several factors including the ability and willingness to pay of contributors and the ability of recipient countries to absorb the funds in verifiable projects for environmental sustainability.

For our numerical example, and purely for illustrative purposes, we assign a per capita GDP threshold of US\$5,000. Thus countries with per capita income in excess of the threshold are potential contributors while countries below the threshold are potential recipients. An illustration of the net CURES receipts (contributions are treated as negative receipts) is provided in Figure 3 to show the smooth transition from recipient to donor countries at the income threshold.

[Put Figure 3 here]

\subsubsection{Donor Countries}


Using data from the World Development Indicators (World Bank 2001), 32 countries are potential contributors to the fund while all other nations are potential recipients. Contributions into the fund, however, would not preclude countries from making additional ODA funding on either a bilateral or multilateral basis. The CURES contributions are determined by the following factors, with an equal weight assigned to each.

(a) Population, whereby more populous countries tend to pay more. For 1999, the population for the 32 contributing countries ranges from less than 1 million to 278 million for United States.

(b) GDP per person in US\$, whereby richer countries tend to pay more. The per capita GDP in 1999 for the 32 countries ranges from US\$5,000 (the income threshold) to US\$36,232 (Switzerland).

(c) Change in adjusted net savings as a proportion of GDP, whereby the greater the increase (or the smaller the decrease) in adjusted net savings, the less a contributing country will tend to pay. For our example, the change in adjusted net savings is defined as the difference in the 5-year moving average in the most recent period for which data is available (1995-1999) and the 5-year moving average in the immediate preceding period (1994-98). The range for the 32 contributing countries is -1 to just above +2 percentage points.

To illustrate how the contributions from donors are calculated, Table 1 gives the normalized scores, CURES country factor and per capita and total contributions for the United States, Japan, Germany and Australia. The United States is the largest country in the contributors group and scores a population factor of 1.0 while its per person income is 
89 percent of that of the country with the highest per capita income, yielding an income factor of 0.89 . Unlike the population and income factors that are increasing in the levels of population and per capita income, respectively, the environmental factor is inversely related to environmental sustainability. Consequently, the lower is the level of environmental sustainability, the larger the normalized environmental factor. For the United States, the change in adjusted net savings as a share of GDP from 1994-1998 to 1995-1999 is minus 0.3 percentage points, which is in the bottom third of the defined range, and thus yields a relatively large environmental factor of 0.77 . Multiplying the three factors, and giving them equal weight, yields a country factor of 0.69 . Scaling this up, along with all other country factors, yields a US contribution of US\$4.1billion, or around US\$15 per person.

Japan has the highest per capita contribution at around US\$18, while Germany's per capita contribution is just below the average of US\$10. Australia, with a per person income close to the mid-point of the distribution, contributes at a below average per capita rate because of a slight increase in adjusted net savings over the defined period.

[Put Table 1 here]

Table 2 compares the contributions and key indicators of the principal contributors into the CURES fund. The United States is the largest absolute contributor to CURES, accounting for 42 percent of global contributions, followed by the European Union (EU) and Japan that pay for 29 percent and 23 percent of the CURES fund respectively. On a per capita basis, the EU's contributions are just over half that of the United States and 
well below the average, because of lower average incomes and improvements in adjusted net savings in a number of European countries over the period 1994-1998 to 1995-1999.

[Put Table 2 here]

The distribution of contributions in relation to per person income is plotted in Figure 4, for all 32 countries (EU disaggregated). The positive correlation between per capita income and contributions reflects the influence of the income factor, while the variation in contributions for any given income level is due to differences in the adjusted net savings indicator. Despite the positive relationship between contributions and GDP per capita, both Table 2 and Figure 4 show that contributions based on GDP alone are markedly different to the CURES funding formula. For example, if the contributions were based solely on total GDP, the US would contribute about eight percent more than the EU, while using the proposed CURES formula it contributes over 40 percent more into the fund than the EU.

[Put Figure 4 here]

Two countries have zero, or close to zero, contributions: Ireland, which increased its adjusted net savings by more than two percentage points during the period analyzed and is, thus, above the cut-off point for contributors; and the Czech Republic with a per capita income at just above the income threshold for contributors. 


\subsubsection{Recipient Countries}

Countries with GDP per capita below US $\$ 5,000$ can potentially receive money from the CURES fund. Receipts from the fund by country are determined by the following criteria.

(a) Population, whereby more populous countries tend to receive more CURES receipts. The population in 1999 for the 100 countries ranges from less than one million to 1.254 billion (China).

(b) GDP per person in US\$, whereby poorer countries tend to receive more CURES receipts. For 1999, the income ranges from just over US\$100 for the poorest African country to US\$5,000, the threshold income level.

(c) Adjusted net savings as a proportion of GDP, whereby countries with the lowest levels of adjusted net savings tend to receive more CURES receipts. We use the 5-year average of adjusted net savings for our calculations that ranges from -36 to +31 as a percentage of GDP.

Table 3 provides an example as to how the CURES receipts are calculated for three recipient countries-Brazil, Indonesia and Nigeria. Brazil is a populous country that receives a relatively small share of CURES funds because it has a relatively high (among recipient countries) per capita income. Indonesia, with a similar adjusted net savings rate, receives an allocation several times higher on a per capita basis because of its lower income level. Nigeria is a very poor country with an exceptionally low adjusted net savings. Consequently, its per capita income and adjusted net savings factors are both 
close to 1, such that Nigeria would receive a per capita CURES receipt more than double the average of all recipient nations.

[Put Table 3 here]

Under the described calculation and weighting method, poor countries with large populations tend to receive more funding. However, a different weighting scheme that assigns, say, a greater importance to the environmental factor would result in a different distribution of receipts and would give greater priority to the level of environmental sustainability. Thus, depending on the weights assigned to the three factors (population, per capita income and environmental sustainability) the distribution of receipts could be very different.

Table 4 presents the 'top 10 list' of recipient countries in terms of absolute receipts. The countries include a mix of large and medium-sized countries with either exceptionally low incomes or low adjusted net savings, or both, such as Nigeria and Ethiopia. Overall, the 10 largest recipient countries account for two thirds of total CURES receipts in our example.

[Put Table 4 here]

Table 5 indicates that the top 10 list of countries in terms of CURES receipts per capita is dominated by smaller countries with either exceptionally low adjusted net savings or per capita income, or both. This group accounts for just 12 percent of global 
CURES receipts, of which half is allocated to Nigeria. At around US\$5 per person per year, receipts to this group are over twice the average per capita level. For every country in Table 5, with the exception of Nigeria, ODA is much higher than the calculated CURES receipts.

[Put Table 5 here]

The overall relationship between CURES receipts and per capita income is shown in Figure 5. All countries with a per capita income of US\$ 700 or less get a higher per person receipt than the average for all recipient countries.

[Put Figure 5 here]

\subsection{Conditionality and Accountability}

In keeping with the experience of intergovernmental transfers in developing countries in the provision of efficient public services (Bird and Smart, 2002), recipient countries receiving CURES receipts would be required to meet conditions for funding. The sole purpose of the conditions would be to ensure funds were used as effectively as possible. These conditions would include a clear objective from the recipient country as to what would be achieved along with a statement of how the CURES receipts would be spent to meet the goal(s), with specified benchmarks to attain the performance targets. This approach would be a significant improvement over past performance of the GEF. For 
instance, Young (2002, p. 211) notes in the second Overall Performance Study of the GEF released in 2002 that the evaluators found that only 12 percent of projects financed by the GEF since 1991 had received final evaluations or completion reports.

To ensure accountability for CURES receipts, no country would be able to receive funds unless they were spent on a verifiable project with measurable benefits towards environmental sustainability. The verification would be undertaken by an independent body either within or linked to the CURES secretariat. Given that failures to achieve agreed-to outcomes could arise from factors beyond the control of recipient countries, each project would have defined 'structural benchmarks' (Adam and Gunning 2002). These benchmarks could also be related to a decision support system, or possibly critical threshold values defined for each project (Nijkamp and Vreeker, 2000). Failure to achieve initial benchmarks would trigger further investigation, and possibly technical assistance, to ensure project objectives were achieved. Persistent failures in meeting benchmarks would incur graduated sanctions culminating in the ultimate sanction of the freezing of all CURES funds allocated to a project. Such conditionality would assist recipient countries to meet targets and would provide a financial incentive to improve environmental sustainability.

To help ensure that CURES receipts are directed to where they generate the greatest return, allocated annual receipts would be transferable between countries. This might occur in two different ways: one, inter-temporal trading of CURES among recipient countries and two, the selling of CURES among recipient countries. Both forms of trading would need to be approved by a CURES secretariat. In the first case, trading would involve 'borrowing' a share of recipient's country's CURES to be repaid with 
interest in the future in the form of CURES. In the second case, CURES would be sold for a financial consideration, but would trade at a discount or at less than its nominal value to reflect the fact that any disbursements from the fund must be spent on verifiable projects with measurable benefits. Regardless of the allocation mechanism, actual disbursements (as opposed to the right to receive a disbursement defined by CURES receipts) to any recipient country would, in every case, be conditional on projects or investments meeting defined criteria for environmental sustainability.

\section{A CURES Case-study: Forest Fires in Indonesia}

To show the potential of CURES to promote SD, we present a case study of the forest fires of Indonesia. The fires are an example of on-going environmental degradation that generates effects that run counter to the objectives of the UN conventions on climate change and biodiversity, but that escapes the funding mechanisms set up under these conventions. Equally as important, the problem is beyond the current means of the Indonesian government to address effectively (Varma 2003).

\subsection{Effects of the fires}

Indonesian forest fires occur mainly on the islands of Kalimantan (Borneo) and Sumatra. They cause the destruction of forests with associated loss of timber and ecosystem services such as flood protection and erosion control, result in biodiversity losses, and release large amounts of carbon into the atmosphere. Smoke from the fires 
also contributes significantly to the 'Asian brown cloud', an area of high semi-permanent air pollution over large parts of Southeast Asia.

The fires in Indonesia were particularly extensive in 1997-98. Over this period, the total area burned is estimated to be 10 million hectares, about half of which was forestland (Applegate et al. 2002). These fires generated an estimated cost of US\$ 21 billion in Indonesia alone, or an amount equal to some eight percent of its GDP (Varma 2003). As a direct result of these fires, a drop in the numbers of rare and endangered animal species has been recorded. Smoldering fires in peat forests were particularly devastating, causing most of the haze problem, as well as generating very large carbon emissions. Page et al. (2002) estimate that between 0.8 and 2.6 gigatons $(1$ gigaton $=1$ billion tons) of carbon were released from peat lands in the 1997-98 fires-equivalent to between 13 percent and 40 percent of total annual global carbon emissions from fossil fuel combustion.

\subsection{How CURES could help}

The fires occur for a combination of reasons-climatic, economic, social and institutional. Fires are particularly extensive in years of drought, which are generally associated with El Niňo-Southern Oscillation events. In such years, fires spread more easily and take longer to be extinguished by rain. A significant cause of fires is clearing. The culprits are both commercial companies that find fire the most cost effective way of clearing native vegetation for establishing plantations, as well as semi-nomadic farmers clearing land for shifting agriculture. In both cases, the damages from fire are largely external to those who set them, and fires are rooted in private economic considerations. 
Fire is also used as a weapon in conflicts between villagers or with plantation companies (Colfer, 2002). In all of these cases, the virtual absence of law enforcement and institutions for fire prevention is at the heart of the problem. In addition, the institutional capacity to detect and fight fires is seriously underdeveloped.

Addressing the problem requires both political will and financial muscle. If the Indonesian government had large financial resources available for both preventing and fighting forest fires, this could provide both the incentive and the means for action. CURES could be the source of funding for an outcome-oriented program to reduce forest fires. A coordinated program for fire prevention and management could comprise a number of measures. Applegate et al. (2002, pp. 303ff.) propose policy initiatives to reduce the occurrence and spread of fires including land-use zoning and management, land clearance, drought and fire prevention and institutional strengthening. CURES could help in each initiative by providing incentive payments to regional governments to implement and enforce zoning and regulations, to fund fire prevention, pay for additional personnel on the ground, and pay for mechanical clearing as well as providing alternative employment for shifting cultivators (Varma 2003), where appropriate. CURES could even be used to buy off formal or informal property rights from plantation companies. This could take the form of annual payments to concession holders, subject to the land in question not being burned.

Under our illustration of a US\$ 10 billion annual CURES fund, Indonesia would receive around US\$ 400 million per year. If additional funds were needed for a limited period of time, for example for buying off land use rights and setting up institutions and technical equipment, Indonesia could borrow additional CURES from the fund and pay 
them back by drawing on its allocation in future years. Continued funding would, however, depend on the money being put to good use, and strict performance standards would have to be applied to avoid the funds being siphoned into other uses. If CURES could go even some way to reduce the incidence and severity of future forest fires in Indonesia, it would make a large contribution to protecting biodiversity and reducing carbon emissions relative to almost any other global policy initiative.

\section{Reforming the GEF}

The proposed CURES funding mechanism shares a number of similarities with the GEF that is managed through the World Bank. In particular, they both represent global funding mechanisms for SD that direct resources from rich to poor countries. There are, however, substantial differences between the two approaches, with several desirable features that are unique to CURES. Given the advantages of CURES, but the fact that the GEF already exists, we argue that the best course of action is to reform the GEF in its next replenishment in 2006 and incorporate at least some, and preferably all, of the desirable features of CURES.

One of the most obvious differences between the existing GEF and CURES is that receipts from the CURES fund would be much more transparent and open than is true with the current GEF. At present, the allocation of funds under the GEF is dependent on the projects brought by countries and NGOs to it, and its changing funding priorities. Under CURES, countries would be able to predict (with a small margin of error) their future receipts as the factors (measures of income, population and environmental 
sustainability) used to calculate CURES receipts would not change substantially from year to year. Thus recipient nations could plan better their development strategies and project implementation. The transparency in funding to countries would also help avoid the perception of political interference in determining payments that has been identified as a potential problem with the GEF (Young 2002, chapter 4).

Another important difference between the two mechanisms is that the contributions into the fund by donor countries will be more equitable with CURES. This is because the richer the country and the poorer its relative environmental sustainability performance, the proportionally greater its contribution. For example, under the GEF the US contributes less than a quarter of the total funds while under the CURES mechanism it would contribute over 40 percent of the total. To illustrate the differences, a comparison of the relative contributions under CURES and the GEF, by selected donors, is presented in Table 6.

[Put table 6 here]

CURES would also help address apparent inequities under the GEF whereby some poor countries (China, Cote d'Ivoire, India, Nigeria, Pakistan, Turkey) are also donors, each making contributions of up to $0.5 \%$ of the total fund. Thus fixing national contributions and receipts to an agreed to formula is both politically neutral in implementation and would favor poorer countries - characteristics that should allow CURES to garner greater international support and enlarge the opportunities for SD planning. 
One of the more useful features of CURES is the added incentive they provide for donor countries to improve their environmental sustainability. In particular, countries that improve their measure of environmental sustainability relative to their peers contribute proportionally less to the fund. This incentive would likely be more than just a financial benefit as it should give the leaders of better performing countries 'bragging rights' both domestically and internationally. In terms of poor countries, the CURES receipts would also provide an important source of funding. Further, with conditionality based on structural benchmarks, critical thresholds and final evaluations and auditing of all funding, CURES would provide strong national incentives to improve environmental sustainability.

Another important benefit of CURES, relative to the GEF, is its in-built flexibility that allows for inter-temporal trade-offs with CURES banking, and improved efficiency in the funding allocation with CURES trading. For example, a country that may have difficulties in absorbing current CURES receipts can 'bank' the funds for future use. In addition, trading of CURES between countries would help promote efficiency in the sense that projects with the highest perceived national benefits could be funded via a market mechanism.

The administration of CURES also offers a number of desirable characteristics in terms of the allocation of funds. Under the GEF, for instance, funding has nominally been targeted to cover 'incremental' or additional costs so as to allow projects with national benefits to generate global benefits (GEF, 2003). Further, funds have primarily been directed to projects that meet the stated objectives of the United Nations environmental conventions, such as the UNFCCC or UNCBD. By contrast, whether projects generate 
national or global benefits is irrelevant in terms of what poor countries have the right to receive in CURES. Thus CURES enlarges the set of potential projects and allows countries to undertake projects that only generate national benefit.

CURES offer an example of what could be achieved with a reformed GEF, should there be a fourth replenishment beyond the current GEF funding round scheduled to end in 2006. A GEF that used the CURES mechanism would be more responsive to recipient country needs, promote greater efficiency with banking and trading, offer the potential of a more streamlined process of disbursement and assessment, and provide additional incentives for rich countries to promote environmental sustainability. Improved sustainability outcomes associated with CURES, relative to the current GEF, may even increase the willingness of donor countries to contribute to the fund while also giving recipient nations a greater role in the funding, planning and implementation of SD.

\section{Concluding Remarks}

It is some thirty years since the first United Nations conference on the environment and over a decade since the United Nations Conference on Environment and Development. Despite some significant gains in terms of livelihood and environmental quality, many of the laudable goals of these conferences remain unrealized.

To help address on going environmental and development problems, a new and innovative mechanism that promotes sustainable development is proposed, called Country Undertakings and Rights for Environmental Sustainability (CURES). The CURES funding mechanism has a number of advantages over existing institutions, such 
as the Global Environmental Facility (GEF). Ideally, CURES would involve all countries and would promote overall environmental sustainability, provide financial incentives for both rich and poor countries to improve national environmental performance, incorporate the principle of common, but differentiated, responsibilities and link incentives to verifiable and measurable accepted performance targets. A reformed GEF that adopted the desirable features of CURES, if widely adopted and funded at a sufficiently high level, would offer a significant boost to global sustainable development and would greatly assist poor countries to address the twin challenges of poverty and environmental degradation.

\section{Acknowledgements}

We are grateful for helpful comments provided by Annette Cowie and Jack Pezzey, and also for the suggestions of two anonymous referees. 


\section{References}

Adam, C.S. and J.W. Gunning. 2002. Redesigning the Aid Contract: Donors' Use of Performance Indicators in Uganda. World Development 30, 2045-2056.

Applegate, G., Smith, R., Fox, J.J., Mitchell, A., Packham, D., Tapper, N. and Baines, G. 2002. Forest fires in Indonesia: Impacts and solutions, in Colfer, C.J.P. and Resosudarmo, A.P. (eds), Which way forward? People, forests, and policymaking in Indonesia. RFF/CIFOR/ISEAS.

Bird, R.M. and M. Smart. 2002. Intergovernmental Fiscal Transfers: International Lessons for Developing Countries. World Development 30, 899-912.

Colfer, C.J.P. 2002. Ten propositions to explain Kalimantan's fires, in Colfer, C.J.P. and Resosudarmo, A.P. (eds), Which way forward? People, forests, and policymaking in Indonesia. RFF/CIFOR/ISEAS.

Ferraro, P.J. and A. Kiss. 2002. Direct Payments to Conserve Biodiversity. Science 298, 1718-1719.

Global Environmental Facility (GEF) 2003, Eligibility Criteria, http://www.gefweb.org/Operational_Policies/Eligibility_Criteria/Incremental_Costs/i ncremenatl_costs.html.

Global Environmental Facility (GEF) Council. 2002. Summary of Negotiations on the Third Replenishment of the GEF Trust Fund, September 19, World Bank.

Hamilton, K. and M. Clemens. 1999. Genuine Savings Rates in Developing Countries. World Bank Economic Review 13 (2), 333-356.

Neumayer, E. 2001. The Human Development Index and Sustainability-A Constructive Proposal. Ecological Economics 39, 101-114. 
Nijkamp, P. and R. Vreeker, 2000. Sustainability Assessment of Development Scenarios: Methodology and Application to Thailand. Ecological Economics 33, 7-27.

Page, S.E., F. Siegert, J.O Rieley, H-D V Boehm, A. Jaya and S. Limin, 2002. The Amount of Carbon Released from Peat and Forest Fires in Indonesia during 1997, Nature 420, 61-65.

Pearce, D., K. Hamilton and G. Atkinson. 1996. Measuring Sustainable Development: Progress on Indicators. Environment and Development Economics 1, 85-101. United Nations. 1992. Report of the United Nations Conference on Environment and Development http://www.un.org/documents/ga/conf151/aconf15126-1annex1.htm.

United Nations. 2002. World Summit on Sustainable Development—Plan of Action. http://www.un.org/jsummit/html/documents/summit_docs/2309_planfinal.htm Van Soest, D. and R. Lensink. 2000. Foreign Transfers and Tropical Deforestation: What Terms of Conditionality? American Journal of Agricultural Economics 82, 389-399. Varma, A. 2003. The economics of slash and burn: a case study of the 1997-98 Indonesian forest fires. Ecological Economics, 46, 159-171.

World Bank. 2002a. GEF Projects. http://www-esd.worldbank.org/gef/projectSummary.cfm.

World Bank. 2002b. Sustainable Development and the Global Environment: The Experience of the World Bank Group-Global Environmental Facility Program.Washington DC: The World Bank. World Bank. 2001. World Development Indicators on CD-ROM. World Bank: Washington D.C. 
World Commission on Environment and Development (WCED). 1987. Our Common Future. Oxford University Press, Oxford.

Young, Z. 2002. A New Green Order: The World Bank and the Politics of the Global Environment Facility. Pluto Press, London. 
Table 1: Examples for calculating contributions to CURES

\begin{tabular}{|c|c|c|c|c|}
\hline & United States & Japan & Germany & Australia \\
\hline \multicolumn{5}{|l|}{ Indicators: } \\
\hline Population (million) $^{\mathbf{a}}$ & 278 & 127 & 82 & 19 \\
\hline GDP/person (US\$'000/year) ${ }^{\mathbf{a}}$ & 33 & 34 & 26 & 21 \\
\hline $\begin{array}{l}\text { Change in adjusted net savings ( } \% \text { of } \\
\text { GDP) }\end{array}$ & -0.3 & -0.6 & 0.0 & 0.2 \\
\hline \multicolumn{5}{|l|}{ Factors (normalized and truncated): } \\
\hline Population factor & 1.00 & 0.45 & 0.30 & 0.07 \\
\hline Income factor & 0.89 & 0.94 & 0.66 & 0.52 \\
\hline Adjusted net savings factor & 0.77 & 0.88 & 0.65 & 0.60 \\
\hline \multicolumn{5}{|c|}{ Multiplication of factors (with equal weights): } \\
\hline Country factor & 0.6889 & 0.3761 & 0.1281 & 0.0212 \\
\hline \multicolumn{5}{|c|}{ Contributions into a US\$10 billion CURES fund: } \\
\hline Total contributions (US\$million/year) & 4,165 & 2,274 & 775 & 128 \\
\hline $\begin{array}{l}\text { Contribution per person } \\
\text { (US\$/person/year) }\end{array}$ & 14.97 & 17.96 & 9.44 & 6.77 \\
\hline
\end{tabular}

Data source: World Bank (2001) and authors' calculations.

a Data for 1999

b Change between 5-year averages 1994-98 and 1995-99.

c Data for the period examined was Genuine Savings. 
Table 2: Contributions to the CURES fund

\begin{tabular}{|c|c|c|c|c|c|c|c|}
\hline & \multicolumn{3}{|c|}{ Contributions to CURES } & \multicolumn{3}{|c|}{ Indicators for CURES calculation } & memo \\
\hline & $\begin{array}{c}\text { US\$/ } \\
\text { person }\end{array}$ & $\begin{array}{c}\text { US\$ } \\
\text { million }\end{array}$ & $\begin{array}{l}\text { share } \\
\text { of total } \\
(\%)\end{array}$ & $\begin{array}{l}\text { Population } \\
\text { (m) }\end{array}$ & $\begin{array}{c}\text { GDP/ } \\
\text { person } \\
\left(\begin{array}{c}\$ 000 s) \\
\mathbf{a}\end{array}\right.\end{array}$ & $\begin{array}{l}\text { Change in } \\
\text { adjusted net } \\
\text { savings } \\
\text { (percentage } \\
\text { points) } \mathbf{b , c}\end{array}$ & $\begin{array}{c}\text { Average } \\
\text { adjusted net } \\
\text { savings 1995- } \\
99\left(\begin{array}{c}\% \\
\text { c }\end{array}\right.\end{array}$ \\
\hline United States & 14.97 & 4,165 & 41.7 & 278.2 & 32.9 & -0.3 & 9.0 \\
\hline Japan & 17.96 & 2,274 & 22.7 & 126.6 & 34.3 & -0.6 & 18.0 \\
\hline $\begin{array}{l}\text { European } \\
\text { Union }\end{array}$ & 7.77 & 2,915 & 29.1 & 375.0 & 22.6 & $\begin{array}{c}\text { average: } 0.1 \text {, } \\
\text { range: }-0.4 \text { to } \\
+2.1\end{array}$ & $\begin{array}{c}\text { average: } 14.3 \text {, } \\
\text { range: } 8.8 \text { to } \\
28.7\end{array}$ \\
\hline Others $^{\mathbf{d}}$ & 3.18 & 646 & 6.5 & 203 & 13.8 & $\begin{array}{l}\text { average: } 0.4 \text {, } \\
\text { range: }-0.8 \text { to } \\
+1.2\end{array}$ & $\begin{array}{l}\text { average: } 13.9 \text {, } \\
\text { range: }-30 \text { to } \\
+41\end{array}$ \\
\hline $\begin{array}{l}\text { Total or } \\
\text { average }\end{array}$ & 10.17 & 10,000 & 100 & 983 & 25.2 & $\begin{array}{c}\text { average: } 0.2 \text {, } \\
\text { range: }-0.8 \text { to } \\
+2.1\end{array}$ & $\begin{array}{l}\text { average: } 12.9 \text {, } \\
\text { range: }-30 \text { to } \\
+41\end{array}$ \\
\hline
\end{tabular}

Data source: World Bank (2001) and authors' calculations.

a Data for 1999

b Change between 5-year averages 1994-98 and 1995-99.

c Data for the period examined was Genuine Savings.

d Comprises Argentina, Australia, Barbados, Canada, Czech Republic, Hong Kong, Israel, Korea (Rep.),

Kuwait, New Zealand, Norway, Saudi Arabia, Singapore, Slovenia, Switzerland and Uruguay. 
Table 3: Examples for calculating CURES receipts

\begin{tabular}{|c|c|c|c|}
\hline & Brazil & Indonesia & Nigeria \\
\hline \multicolumn{4}{|l|}{ Indicators: ${ }^{\mathbf{a}}$} \\
\hline Population (million) & 168 & 207 & 124 \\
\hline $\begin{array}{l}\text { GDP/person } \\
\text { (US\$'000/year) }\end{array}$ & 4.5 & 0.7 & 0.3 \\
\hline $\begin{array}{l}\text { Adjusted net savings } \\
(\% \text { of GDP })^{\mathbf{b}}\end{array}$ & 12.1 & 16.5 & -15.2 \\
\hline \multicolumn{4}{|c|}{ Factors (normalized and truncated): } \\
\hline Population factor & 0.134 & 0.165 & 0.098 \\
\hline Income factor & 0.105 & 0.862 & 0.943 \\
\hline $\begin{array}{l}\text { Adjusted net savings } \\
\text { factor }\end{array}$ & 0.465 & 0.392 & 0.920 \\
\hline \multicolumn{4}{|c|}{ Multiplication of factors (with equal weights): } \\
\hline Country factor & 0.00656 & 0.05585 & 0.08574 \\
\hline \multicolumn{4}{|c|}{ Receipts from a US\$10 billion CURES fund: } \\
\hline $\begin{array}{l}\text { Total receipts } \\
\text { (US\$million/year) }\end{array}$ & 48.9 & 416.6 & 639.6 \\
\hline $\begin{array}{l}\text { Receipts per person } \\
\text { (US\$/person/year) }\end{array}$ & 0.29 & 2.01 & 5.16 \\
\hline
\end{tabular}

Data source: World Bank (2001) and authors' calculations.

a Data for 1999

b Data for the period examined was Genuine Savings. 
Table 4: Receipts from the CURES fund: the 10 largest recipient countries

\begin{tabular}{|l|c|c|c|c|c|c|}
\hline & \multicolumn{3}{|c|}{ CURES receipts } & \multicolumn{3}{c|}{ Indicators for CURES calculation } \\
\hline & $\begin{array}{c}\text { US\$/ } \\
\text { person }\end{array}$ & $\begin{array}{c}\text { US\$ } \\
\text { (millions) }\end{array}$ & $\begin{array}{c}\text { share of } \\
\text { total } \\
(\%)\end{array}$ & $\begin{array}{c}\text { Population } \\
\text { (millions) }\end{array}$ & $\begin{array}{c}\text { US\$ } \\
\text { GDP/per } \\
\text { capita } \mathbf{b} \text { ( }\end{array}$ & $\begin{array}{c}\text { Adjusted net savings, } \\
\text { average from 1995-99 } \\
\text { to 95-99 (\% of GDP) }\end{array}$ \\
\hline India & 2.86 & 2,854 & 28.5 & 998 & 448 & 8.3 \\
\hline China & 0.84 & 1,056 & 10.6 & 1,254 & 789 & 29.9 \\
\hline Nigeria & 5.16 & 640 & 6.4 & 124 & 283 & -15.2 \\
\hline Pakistan & 3.39 & 457 & 4.6 & 135 & 431 & 2.6 \\
\hline Indonesia & 2.01 & 417 & 4.2 & 207 & 688 & 16.5 \\
\hline Bangladesh & 2.98 & 381 & 3.8 & 128 & 360 & 7.6 \\
\hline Ethiopia & 4.71 & 296 & 3.0 & 63 & 103 & -8.5 \\
\hline $\begin{array}{l}\text { Russian } \\
\text { Federation }\end{array}$ & 1.63 & 238 & 2.4 & 146 & 2,746 & 3.6 \\
\hline Vietnam & 2.99 & 232 & 2.3 & 78 & 370 & 7.5 \\
\hline Philippines & 2.54 & 188 & 1.9 & 74 & 1,031 & 16.9 \\
\hline $\begin{array}{l}\text { Sum of the 10 } \\
\text { largest recipients }\end{array}$ & 2.11 & 6,757 & 67.6 & 3,205 & 696 & 10.4 \\
\hline $\begin{array}{l}\text { 90 remaining } \\
\text { recipients }\end{array}$ & 2.11 & 3,243 & 32.4 & 1,535 & 2,040 & $\mathbf{1 3 . 1}$ \\
\hline total or average & $\mathbf{2 . 1 1}$ & $\mathbf{1 0 , 0 0 0}$ & $\mathbf{1 0 0 . 0}$ & $\mathbf{4 , 7 4 0}$ & $\mathbf{1 , 1 3 1}$ & \\
\hline
\end{tabular}

Data source: World Bank (2001) and authors' calculations.

a Data for 1999

b Data for the period examined was Genuine Savings. 
Table 5: Receipts from the CURES fund: the 10 countries with the highest per capita payments

\begin{tabular}{|l|c|c|c|c|c|c|}
\hline & \multicolumn{3}{|c|}{ CURES receipts } & \multicolumn{3}{c|}{ Indicators for CURES calculation } \\
\hline & $\begin{array}{c}\text { US\$/ } \\
\text { person }\end{array}$ & $\begin{array}{c}\text { US\$ } \\
\text { (millions) }\end{array}$ & $\begin{array}{c}\text { share of } \\
\text { total } \\
(\%)\end{array}$ & $\begin{array}{c}\text { Population } \\
\text { (millions) }\end{array}$ & $\begin{array}{c}\text { US\$ } \\
\text { GDP/ } \\
\text { per } \\
\text { capita } \\
\mathbf{a , b}\end{array}$ & $\begin{array}{c}\text { Adjusted net savings, } \\
\text { average from 1995-99 } \\
\text { to 95-99 (\% of GDP) }\end{array}$ \\
\hline Eritrea & 5.76 & 23 & 0.2 & 4 & 162 & -30.9 \\
\hline Yemen, Rep. & 5.47 & 93 & 0.9 & 17 & 400 & -22.2 \\
\hline Lesotho & 5.46 & 11 & 0.1 & 2 & 415 & -36.6 \\
\hline Armenia & 5.37 & 20 & 0.2 & 4 & 484 & -21.5 \\
\hline Azerbaijan & 5.35 & 43 & 0.4 & 8 & 502 & -32.1 \\
\hline Nigeria & 5.16 & 640 & 6.4 & 124 & 283 & -15.2 \\
\hline Mauritania & 4.97 & 13 & 0.1 & 3 & 369 & -14.2 \\
\hline Sierra Leone & 4.95 & 24 & 0.2 & 5 & 135 & -11.3 \\
\hline Haiti & 4.73 & 37 & 0.4 & 8 & 551 & -13.6 \\
\hline Ethiopia & 4.71 & 296 & 3.0 & 63 & 103 & -8.5 \\
\hline
\end{tabular}

Data source: World Bank (2001) and authors' calculations.

a Data for 1999

b Data for the period examined was Genuine Savings.

Table 6: Percentage of Total Contributions by Selected Donors under CURES and Current GEF

\begin{tabular}{|l|c|c|}
\hline & CURES & GEF (3 \\
\hline & & \\
\hline United States & 41.7 & 22.2 \\
\hline EU & 29.2 & 46.3 \\
\hline Japan & 22.7 & 18.8 \\
\hline
\end{tabular}

Sources: GEF (2002) and authors' calculations. 
Figure 1: Change in Adjusted Net Savings and Per Capita GDP (Donor Countries)

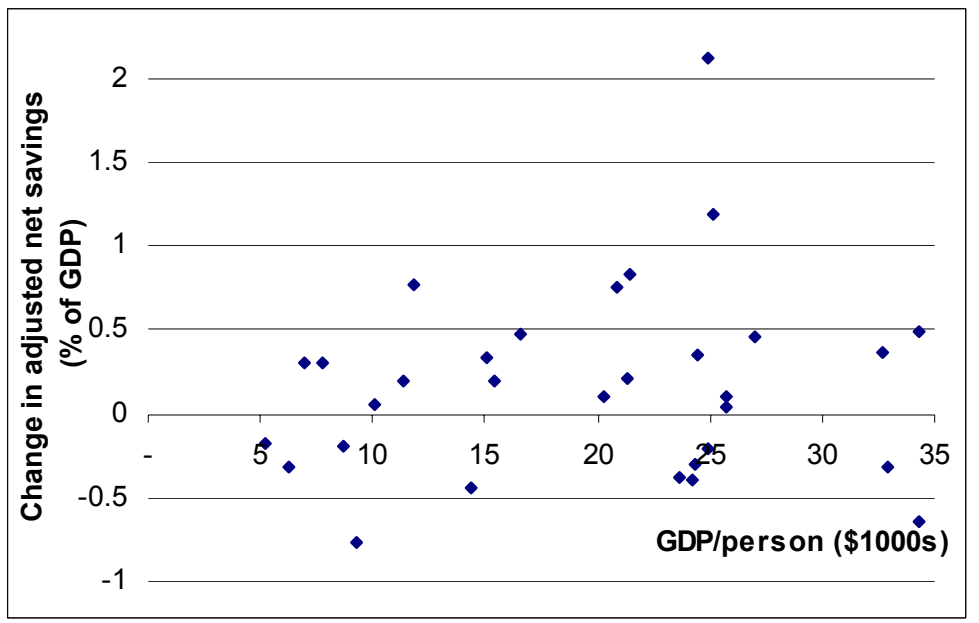

Note: Change in adjusted net savings is difference in 5-year moving average between 1995-99 and 1994-98. The data used is for the period when Adjusted Net Savings were known as Genuine Savings. Differences may exist in the two series.

Figure 2: Level of Adjusted Net Savings and Per Capita GDP (Recipient Countries)

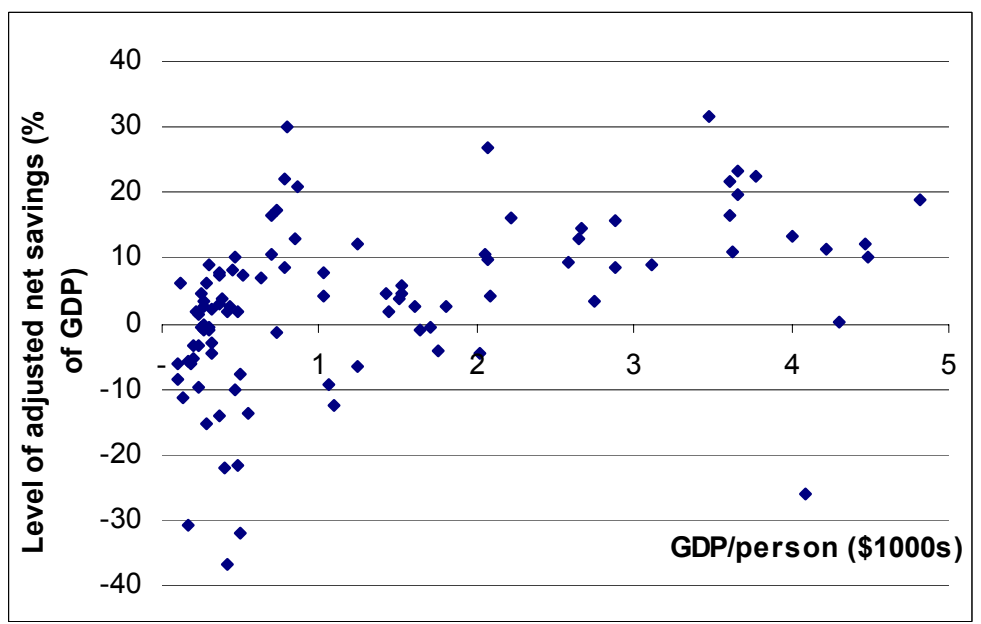

Note: Data used is for 1999 when Adjusted Net Savings were known as Genuine Savings. Differences may exist in the two series. 
Figure 3: Net CURES receipts and Per Capita GDP

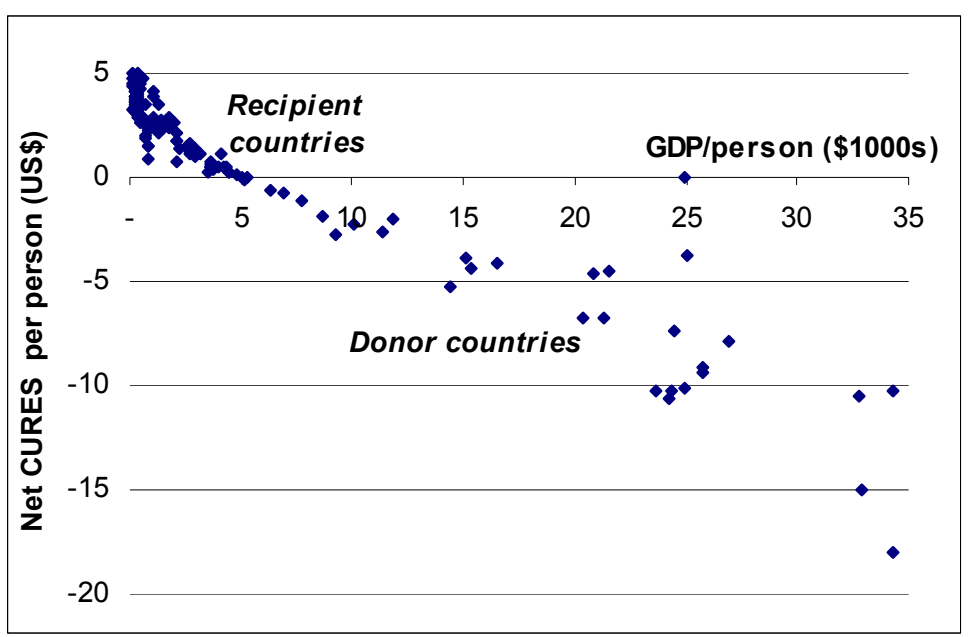

Figure 4: Net CURES Receipts and Per Capita GDP

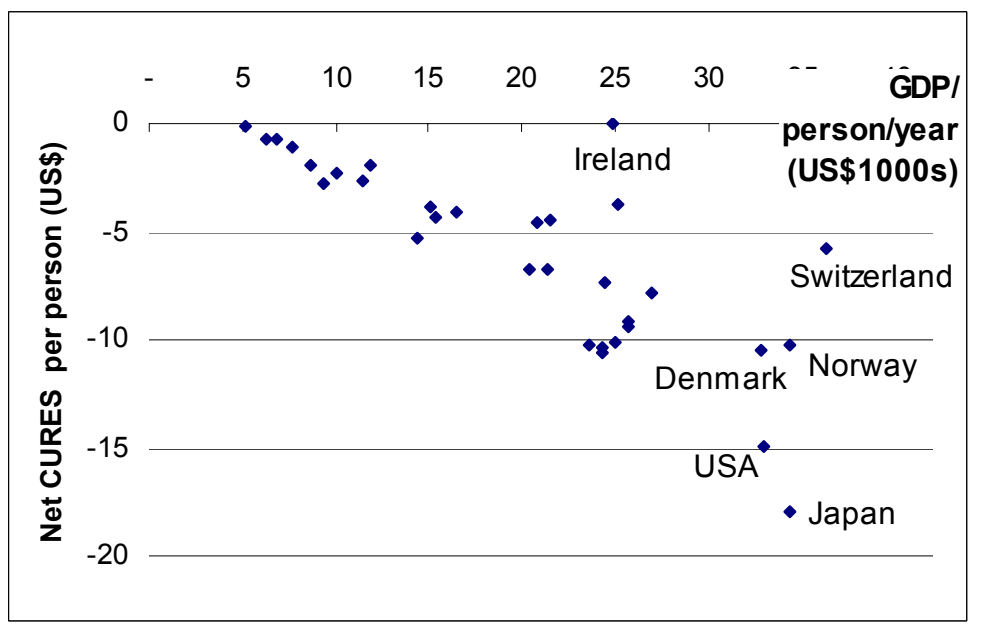


Figure 5: CURES contributions and Per Capita GDP

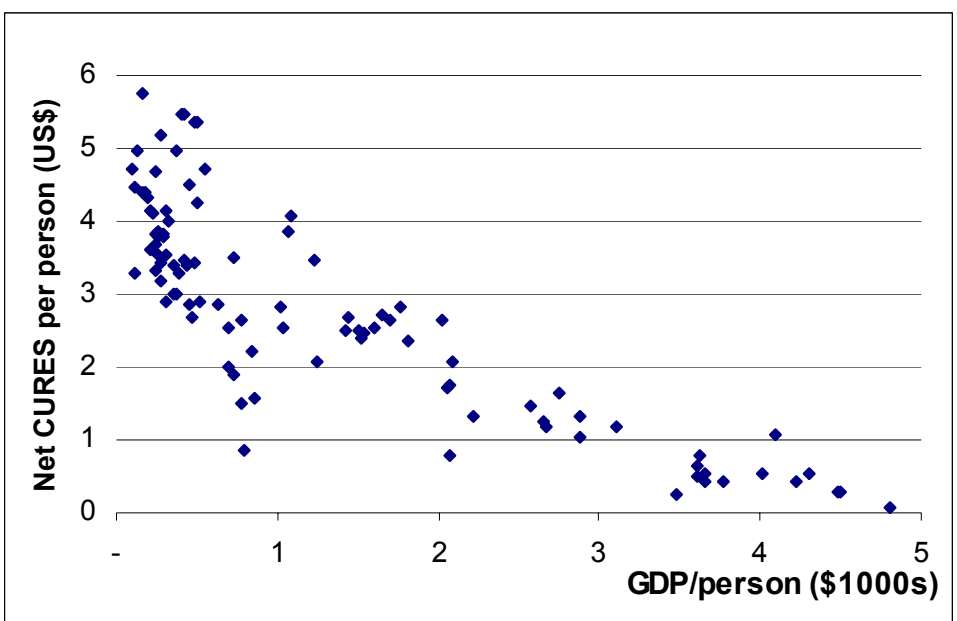

